International Journal of Social Science And Human Research

ISSN(print): 2644-0679, ISSN(online): 2644-0695

Volume 04 Issue 07 July 2021

DOI: $10.47191 / \mathrm{ijsshr} / \mathrm{v} 4-\mathrm{i} 7-42$, Impact factor-5.586

Page No: $1864-1869$

\title{
The Urgency of Public Prosecution Service of the Republic of Indonesia in The Settlement of Replacement Money in Criminal Acts of Corruption Based on Law Number 3 of 1971
}

\author{
Lusiana Lamture, Supardi. S \\ Faculty of Law, University of Pembangunan Nasional Veteran Jakarta
}

\begin{abstract}
In ensnaring the corruptors, not from the upstream, but from the downstream, namely by tracing where the flow of corruption funds ends up. It must be understood that a corruptor who then drains the proceeds of corruption means that he has committed two crimes at once. Therefore, the follow the money method is more effective than the follow The Suspect method, namely the handling of criminal acts that prioritize the perpetrators of crimes. With the follow the money approach, activities to hide or disguise the proceeds of corruption can be prevented and eradicated. However, this must still be regulated so that its implementation can be carried out in a concrete manner so that there is no legal vacuum in the implementation of its execution by the Indonesian Prosecutor's Office. The data collection technique in this research is using the library research method. While the analysis technique carried out on the legal materials that have been collected by the author will be done deductively. The results of this study indicate that the regulation of replacement money in criminal acts of corruption is contained in Law Number 3 of 1971 and has been revoked and amended by Law Number 20 of 2001 jo. so that in this case, there is an important role by the Attorney General's Office of the Republic of Indonesia, finally the Attorney General's Office issued Perja Number PER-020/A/JA/07/2014 and then upgraded to Perja Number 19 of 2020 and followed up with a Circular Letter of the Deputy Attorney General for Civil and Administrative Countries with Number SE-001/G/Gs/03/2021 dated March 26, 2021.
\end{abstract}

KEYWORDS: Crime, Corruption, Substitute Money.

\section{INTRODUCTION}

The government's and law enforcement officers' roles and strategies in corruption eradication are to adopt policies and maximize the function of law enforcement. Dealing with corruption can be accomplished through organizational reforms aimed at avoiding circumstances where one employee has monopoly power and the authority to act, but little accountability. Corruption can also be addressed by imposing rule-of-law laws in order to minimize governmental losses as a result of corruption. ${ }^{1}$

In the context of recouping state financial losses, Law No. 3 of 1971 on the Eradication of Criminal Acts of Corruption provides for additional penalties such as confiscation of assets, goods, or assets obtained through criminal acts of corruption, including goods or assets that replace them, and payment of replacement money. This is an additional provision that is a sanction imposed on corrupt perpetrators.

Although Law Number 3 of 1971 did provide for the imposition of a criminal payment of replacement money, the provisions in it are contradictory with the concept of imposing a criminal payment of replacement money, which is to maximize the return of state funds. This is due to the fact that Law Number 3 of 1971 does not include additional punishment formulations in the form of confiscation of other assets belonging to the convict if the convict does not pay replacement money.

As a result, the renewal of the replacement money arrangement in corruption crimes has been revised to include a solution in the circumstance that the perpetrator fails to pay the replacement money. This is governed by Article 18 paragraph (2) of Law No. 31 of 1999 Concerning the Eradication of Criminal Acts of Corruption. If the convict does not pay the replacement money within 1 (one) month of the court's decision gaining permanent legal force, the Indonesian Prosecutor's Office may seize and auction off the convict's assets to cover the replacement money.

R Wiyono argued that, under the formulation of Article 18 paragraph (2) above, which provides a grace period for payment of replacement money of at least 1 (one) month after the decision has permanent legal force, the Indonesian Prosecutor's Office can determine the stage of payment of replacement money if the conditions cannot be met beyond the one-month grace period. If the

${ }^{1}$ Robert Klitgaard, Membasmi Korupsi. (Jakarta : Obor Indonesia, 2001), p. 98 
The Urgency of Public Prosecution Service of the Republic of Indonesia in The Settlement of Replacement Money in Criminal Acts of Corruption Based on Law Number 3 of 1971

stated time limit has passed and the criminal is unable to pay the replacement money, the Indonesian Prosecutor's Office may seize the convict's property and auction it off to cover the replacement money. ${ }^{2}$

According to Law Number 16 of 2004 concerning Public Prosecution Service of the Republic of Indonesia, the authority to execute decisions on criminal cases that have permanent legal force is the Public Prosecution Service of the Republic of Indonesia. The normative provisions that are coercive in nature will greatly affect the success of the State Attorney in carrying out the execution of the penalty for paying compensation.

According to Adami Chazawi, the purpose of paying Replacement Money (UP) for Corruption Crimes is to recoup losses caused by corruption. Yudi Kristiana agrees with Adami Chazawi that additional criminal sanctions in the form of payment of replacement money are important, because one of the goals of eradicating corruption is to recover state financial losses. ${ }^{3}$

Replacement money, as an additional crime in corruption cases, must be interpreted as a form of punishment for those who break the law. This means that the payment of replacement money is part of the essence of punishment in the form of suffering, misery, or as a response to social balance due to corruption. Punishment, according to Lobby Lukman, aims to:

1. Prevent people from committing criminal acts by enforcing legal norms for community protection.

2. Socializing prisoners through coaching in order for them to become good and useful citizens

3. Resolving conflicts caused by criminal acts, restoring balance and bringing a sense of peace in society

4. Release the guilt of prisoners. ${ }^{4}$

The state is compelled to recover state money that has been lost owing to illegal acts of corruption in conformity with the spirit that underlies the concept of substitute money punishment. These attempts have been in place since the adoption of Law No. 3 in 1971, but the Prosecutor's Office has not been able to refund the money obtained from the proceeds of a criminal act of corruption.

According to the Financial Report of the Public Prosecution Service of the Republic of Indonesia Audited Year 2020, it presents the balance of Non-Tax State Receivables (PNBP) which consists of Replacement Money of Rp. 18,774,172,885,802.00, as much as Rp. 9,852,836,276,102.68 is the arrears of payment of replacement money, as determined by Law Number 3 of 1971 concerning Eradication of Corruption Crimes. This means that $+70 \%$ of the attorney's receivables are derived from arrears of replacement money which was decided based on Law Number 3 of 1971. Therefore, the replacements of the problem of paying compensation for criminal acts of corruption that was sentenced based on Law Number 3 of 1971 can be said to have failed and left a big problem for the Public Prosecution Service of the Republic of Indonesia as the executor.

In accordance with this background, the author is interested in conducting research on issues related to replacement money which is formulated with the title The Urgence of Attorney General of the Republic of Indonesia in the Settlement of Replacement Money in Criminal Acts of Corruption Based on Law Number 3 of 1971

\section{RESEARCH QUESTIONS}

1. How is the arrangement of replacement money in criminal acts of corruption in Indonesia?

2. How is the implementation of the settlement of replacement money that has been decided by the court based on Law Number 3 of 1971 concerning the Eradication of Criminal Acts of Corruption?

\section{RESEARCH METHOD}

The data collection technique in this study uses library research which is carried out by examining various secondary data sources in the form of books, journals, legislation and other legal publications that are relevant to the research topic. This study used both a statutory and a conceptual approach. The author's legal materials will be analyzed deductively, that is, by drawing conclusions from a general problem to the specific issues at hand. This is done to address the legal issues addressed in this study.

\section{THEORITICAL FRAMEWORK}

Legal Purpose Theory The legal purpose put forward by various experts are also identified as legal objectives. The three objectives of the law are legal certainty, justice, and expediency. First, legal certainty, as one of the law's purposes, can be considered part of the attempt to achieve justice. The implementation or enforcement of the law against an action, regardless of who performs it, is the fundamental form of legal certainty. Everyone can forecast what will happen if they perform particular legal activities if they have legal certainty. To implement the ideal of equality before the law, without discrimination, certainty is required. ${ }^{5}$ Second, legal justice is the glue of the order of civilized social life. The law was enacted so that each individual member of the community,

\footnotetext{
${ }^{2}$ Ibid., p. 35

${ }^{3}$ Yudi Kristiana, Pemberantasan Tindak Pidana Korupsi, Perspektif Hukum Progresif, (Yogyakarta : Thafa Media, 2016 ), p. 60.

${ }^{4}$ Eti Laila Kholis, Pembayaran Uang Pengganti Dalam Perkara Korupsi, (Jakarta : Solusi Publishing, 2010), p. 6.

${ }^{5}$ Muhammad Erwin, Filsafat Hukum, (Jakarta: Raja Grafindo Persada, 2012), p.123
} 


\section{The Urgency of Public Prosecution Service of the Republic of Indonesia in The Settlement of Replacement Money in Criminal Acts of Corruption Based on Law Number 3 of 1971}

as well as state officials, take the required steps to maintain social links and fulfill the goals of living together, or vice versa, so as not to jeopardize the rule of law. Because justice has been breached, the social order will be upset if the required action is not carried out or a prohibition is violated. Third, Legal Benefits is the most objective basis for determining if a policy or action provides benefits or useful results for the people concerned, or, opposite, losses. If it is related to the law's good and bad, it must be measured in terms of the good and terrible effects created by the law's application. A new legal provision can be deemed beneficial if the outcomes of its implementation include goodness, maximum happiness, and minimal suffering.

Responsive Legal Theory Philippe Nonet and Philip Selznick popularized the term responsive law in their article "Law and Society in Transition Toward Responsive Law." Both of them use the word to criticize legal theory that emphasizes formalism over actuality. According to Robert A. Kagan, who wrote the introduction to the newest edition of Nonet and Selznick's work, the legislation often appears restrictive and very rigid. ${ }^{6}$ Responsive Law is defined as the use of law to adapt to societal needs and ambitions. The law is developed as a judicial supremacy system in this type, which places the principle of "the rule of law" as a result of the rechtstaat understanding, which means that the law developed has policy objectives and a juridical elaboration of the government's policy reactions, as well as the importance of the participation of groups and individuals who are involved in determining state policy. ${ }^{7}$ This sort of law genuinely leads to the realization of the principles embodied in the community's ideals, political will, and juridical will. These values cannot be considered as political data that can be read in the explanation of government policies, but these values must be clearly reflected in the practice of using and implementing the law, so that in their appreciation these values are able to give direction to political and legal life

\section{RESULTS AND DISCUSSION}

Article 34 of Law Number 3 of 1971 Concerning the Eradication of Criminal Acts of Corruption stipulates the regulation regarding replacement money as a sanction imposed on perpetrators of criminal acts of corruption, which stipulates that in addition to the criminal provisions referred to in the K.U.H.P. then as additional punishment including: ${ }^{8}$

a. Confiscation, whether by the crime or wholly or partially, of a tangible and intangible fixed or immovable good, as well as the opposite price of goods substituting the goods, whether the goods or price opposed to that which was committed or was obtained in respect of that criminal act of corruption;

b. Confiscation, where criminal act of corruption is committed, of tangible and intangible fixed and intangible goods, as well as the opposite price for the goods which replace them, whether the goods are or the opposite price is the legal person, but the crime is related to goods which can be confiscated in accordance with the provisions mentioned.

c. Payment in the maximum amount of replacement money equivalent to assets derived from corruption.

Furthermore, Article 18 of Law Number 3 of 1971 concerning the Eradication of Corruption Crimes states that:

(1) Each defendant is obliged to provide information regarding all his assets and the assets of his wife/husband, children and every person, as well as bodies suspected of having a relationship with the case in question if requested by the judge

(2) If the defendant is unable to provide satisfactory information to the court session regarding the source of wealth that is not balanced with his income or the source of his additional wealth, this information can be used to strengthen the testimony of each witness that the defendant has committed a criminal act of corruption. ${ }^{9}$

In order to carry out the law's mandate regarding replacement money in corruption cases, the Supreme Court issued Circular Letter of the Supreme Court Number 4 of 1988 concerning the Execution of Penalties for Replacement Money, which indicated that:

1. In the case of a criminal imposition of payment of substitute money, the convict cannot determine imprisonment as a substitute if the replacement money is not paid.

2. The execution of the penalty for paying replacement money, if carried out by the Prosecutor, no longer necessitates court intervention, for example, in the form of a confiscation permit as specified in the stipulation and others. This is based on the belief that the confiscation of the convict's property is still an implementation of the judge's decision..

3. Only if in the implementation this time the amount of goods owned by the convict is no longer sufficient, the rest if it will still be billed by the Prosecutor's Office on another occasion must be submitted through a civil lawsuit in court. ${ }^{10}$

\footnotetext{
${ }^{6}$ Robert.A.Kagan, Introduction to Transaction Edition, dalam Philippe Nonet dan Philip Selznick, Law and Society in Transition Towards Responsive Law, (New Jersey:Transcation Publishers, 2001), p. 6

${ }^{7}$ Satjipto Rahardjo, Negara Hukum yang Membahagiakan Rakyatnya, cetakan kedua (Yogyakarta: Genta Publishing, 2009), p. 17

${ }^{8}$ Indonesia, Law Number 3 of 1971 concerning Eradication of Criminal Acts of Corruption, Article 34. State Gazette of 1971, Number 19

${ }^{9}$ Ibid, Article 18.

${ }^{10}$ Indonesia, Circular Letter of the Supreme Court Number 4 of 1988 concerning Execution of Penalties for Replacement Money, Points $1-3$.
} 


\section{The Urgency of Public Prosecution Service of the Republic of Indonesia in The Settlement of Replacement Money in Criminal Acts of Corruption Based on Law Number 3 of 1971}

In order to address the issue of replacement money for cases of criminal acts of corruption decided under Law No. 3 of 1971, the Public Prosecution Service of the Republic of Indonesia issued Regulation of the Attorney General (Perja) Number PER020/A/JA/07/2014 concerning Instructions for Implementation of Settlement of Replacement Money Decided by Court Based on Law No. 3 of 1971 in 2014. However, the regulation cannot be effective because it is not in accordance with the needs and developments in the settlement of replacement money arrears as decided by the court under Law No. 3 of 1971 , then in 2020 the Indonesian Prosecutor's Office issued Regulation of the Public Prosecution Service of the Republic of Indonesia Number 19 of 2020 concerning Settlement of Replacement Money Decided by Courts Based on Law Number 3 of 1971 concerning Eradication of Acts of Corruption and followed up with a Circular Letter of the Deputy Attorney General for Civil and State Administration with Number SE- 001/G/Gs/03/2021 dated March 26, 2021 concerning Technical Guidelines for Settlement of Arrears of Replacement Money Decided Based on Law Number 3 of 1971 concerning Eradication of Criminal Acts of Corruption.

The process of settling replacement money arrears in accordance with the Regulation of Public Prosecution Service of the Republic of Indonesia No. 19 of 2020, which includes:

1. Data collection and inventory of reimbursements

2. Reimbursement Validation

3. Reimbursement claims, asset tracking, and billing

4. Proposal for the Elimination of Replacement Money.

Some of the replacement money arrangements referred to herein have been implemented successfully. Various cases concerning replacement money in the form of civil lawsuits were solved through litigation. The settlement of litigation shall take place through a civil suit of the convict or ex-convict if the non-litigation settlement has failed or the convict or ex-convict does not fulfill their obligations under the contract to make refund or replacement money installments and the convict does not have the property to pay the replacement money. ${ }^{11}$ As in the case of replacement money contained in Decision Number 27/Pdt.G/XI/2013.PN LBBS which has paid off on 15 December 2015 with a Non-Tax Deposit Letter (SSBP) Number 208 in the amount of Rp. 108,901,500,-. Other cases are contained in Decision Number 22/Pdt.G/2014/PN.Bsk in which the heirs concerned have paid off with SSBP No. 15/3/2015 Rp. 16,224,555,-- ${ }^{12}$

Aside from the litigation mechanism, there is also a non-litigation mechanism implemented through the installment mechanism. The success of this non-litigation effort can be seen from the creation of an agreement between the convict or heir and the prosecutor's office represented by JPN to repay the arrears of the replacement money every month. This is as stated in the Bukittinggi Kejari where the convict or his heirs make payments in installments of Rp. 300,000, - for each month. In addition, there is also a replacement money case at the Samarinda Kejari where the replacement money that must be paid is Rp.74,477,766,- and until now the installments are still being made and have not been paid off and the remaining Rp. $35,427,766,-.^{13}$.

If the convict or ex-convict no longer possesses the property to pay the replacement money and attempts to settle the first level of settlement are unsuccessful, arrangements for settlement of replacement money through the abolition of replacement money are undertaken. ${ }^{14}$

Settlement of Replacement Money through a proposal to abolish Replacement Money is submitted based on the proposal of the head of the district attorney's office to the Public Prosecution Service of the Republic of Indonesia through the Head of the High Prosecutor's Office on the grounds that the convict or former convict does not have the ability to pay replacement money, Court decisions and criminal case files related to the decision on Replacement Money payment are no longer found or lost, as are civil court decisions refusing or declaring the Replacement Money lawsuit filed by the State Attorney Attorney against the convicts or ex-convicts as having permanent legal force. ${ }^{15}$

\section{CONCLUSIONS}

According to the explanation above, the regulation regarding replacement money in corruption crimes is constituted in Law Number 3 of 1971 concerning Eradication of Criminal Acts of Corruption, which has been revoked and amended by Law Number 20 of 2001 concerning Amendments to Law Number 31 of 1999 concerning the Eradication of Corruption Crimes.

\footnotetext{
${ }^{11}$ Indonesia, Prosecutor's Office Regulation of the Republic of Indonesia Number 19 of 2020 concerning Settlement of Replacement Money Decided by Courts Based on Law Number 3 of 1971 concerning Eradication of Criminal Acts of Corruption, Article 14..

12 B.S. Sri Marsita, Optimalisasi Penyelesaian Tunggakan Uang Pengganti yang Diputus Berdasarkan Undang-Undang Nomor 3 Tahun 1971 Tentang Pemberantasan Tindak Pidana Korupsi, (Jakarta: Pusat Penelitian dan Pengembangan Kejaksaan Agung, 2016), p. 100

${ }^{13}$ Ibid., p. 101

${ }^{14}$ Indonesia, Prosecutor's Office Regulation of the Republic of Indonesia Number 19 of 2020 concerning Settlement of Replacement Money Decided by Courts Based on Law Number 3 of 1971 concerning Eradication of Criminal Acts of Corruption, Article 17

${ }^{15}$ Indonesia, Prosecutor's Office Regulation of the Republic of Indonesia Number 19 of 2020 concerning Settlement of Replacement Money Decided by Courts Based on Law Number 3 of 1971 concerning Eradication of Corruption Crimes, Article 18.
} 


\section{The Urgency of Public Prosecution Service of the Republic of Indonesia in The Settlement of Replacement Money in Criminal Acts of Corruption Based on Law Number 3 of 1971}

In this case, the Attorney General's Office of the Republic of Indonesia has an important role in issuing the Attorney General's Regulation (Perja) Number PER-020/A/JA/07/2014 concerning Instructions for the Implementation of Settlement of Compensation Decisions by the Court Based on Law Number 3 of 1971 concerning Eradication of Corruption and then upgraded with the Regulation of the Prosecutor's Office of the Republic of Indonesia Number 19 of 2020 concerning the Settlement of Replacement Money Decided by the Court Based on Law Number 3 of 1971 concerning the Eradication of Acts of Corruption and followed up with a Circular Letter of the Deputy Attorney General for Civil and State Administration Number SE-001/G/Gs/03/2021 dated March 26, 2021 concerning Technical Instructions for Settlement of Arrears of Replacement Money Decided Based on Law Number 3 of 1971 concerning Eradication of Criminal Acts Corruption.

Public Prosecution Service of the Republic of Indonesia can complete the implementation of the settlement of replacement money that was decided by the court based on Law Number 3 of 1971 concerning the Eradication of Criminal Acts of Corruption through litigation and non-litigation efforts. Litigation efforts can take the form of civil lawsuits, whereas non-litigation efforts are carried out through an installment mechanism that requires the convict or his heirs to pay the Prosecutor's Office every month.

Settlement of Replacement Money through the elimination of Replacement Money based on the stipulation of the Deputy Attorney General for Civil and State Administration on behalf of the Public Prosecution Service of the Republic of Indonesia can be submitted if the first level settlement efforts are unsuccessful and the convict/ex-convict no longer has the property to pay the Replacement Money and has complied with the requirements contained in the Regulation of the Prosecutor's Office of the Republic of Indonesia Number 19 of 2020 Settlement of Replacement Money Decided by the Court Based on Law Number 3 of 1971 concerning Eradication of Acts of Corruption.

\section{REFERENCES}

\section{Legislations:}

1) Indonesia, Law Number 3 of 1971 concerning Eradication of Criminal Acts of Corruption, State Gazette of 1971, Number 19

2) Indonesia, Law Number 31 of 1999 concerning Eradication of Criminal Acts of Corruption, State Gazette of 1999, Number 138

3) Indonesia, Law Number 20 of 2001 concerning Amendments to Law Number 31 of 1999 concerning Eradication of Criminal Acts of Corruption, State Gazette of 2001 Number 134.

4) Indonesia, Prosecutor's Office Regulation of the Republic of Indonesia Number 19 of 2020 concerning Settlement of Compensation Payments Decided by Courts Based on Law Number 3 of 1971 concerning Eradication of Criminal Acts of Corruption, State Gazette of 2020, Number 1022.

5) Indonesia, Attorney General Regulation Number PER-020/A/JA/07/2014 concerning Guidelines for the Implementation of Settlement of Replacement Money Decided by Courts Based on Law Number 3 of 1971 concerning Eradication of Corruption Crimes.

6) Indonesia, Circular Letter of the Deputy Attorney General for Civil and State Administration Number SE001/G/Gs/03/2021 dated March 26, 2021 concerning Technical Instructions for Settlement of Arrears of Replacement Money Decided Based on Law Number 3 of 1971 concerning Eradication of Acts Corruption Crime

7) Indonesia, Circular Letter of the Supreme Court Number 4 of 1988 concerning the Execution of Penalties for Replacement Money.

\section{Books:}

1) Robert Klitgaard, Membasmi Korupsi. (Jakarta : Obor Indonesia, 2001)

2) Supardi. S, Perampasan Harta Hasil Korupsi; Perspektif Hukum Pidana yang Berkeadilan, (Jakarta : Prenadamedia Group, 2018)

3) Adami Chazawi, Hukum Pidana Korupsi di Indonesia, (Jakarta : Rajawali Pers, 2016)

4) Yudi Kristiana, Pemberantasan Tindak Pidana Korupsi, Perspektif Hukum Progresif, (Yogyakarta : Thafa Media, 2016)

5) Eti Laila Kholis, Pembayaran Uang Pengganti Dalam Perkara Korupsi, (Jakarta : Solusi Publishing, 2010)

6) Kimberly Ann Elliott, Korupsi dan Ekonomi Dunia, (Jakarta : Yayasan Obor Indonesia, 1999)

7) Satjipto Rahardjo, Ilmu Hukum, (Bandung: Citra Aditya Bakti, 2012)

8) Muhammad Erwin, Filsafat Hukum, (Jakarta: Raja Grafindo Persada, 2012)

9) Robert.A.Kagan, Introduction to Transaction Edition, dalam Philippe Nonet dan Philip Selznick, Law and Society in Transition Towards Responsive Law, (New Jersey:Transcation Publishers, 2001)

10) Satjipto Rahardjo, Negara Hukum yang Membahagiakan Rakyatnya, cetakan kedua (Yogyakarta: Genta Publishing, 2009) 
The Urgency of Public Prosecution Service of the Republic of Indonesia in The Settlement of Replacement Money in Criminal Acts of Corruption Based on Law Number 3 of 1971

11) B.S. Sri Marsita, Optimalisasi Penyelesaian Tunggakan Uang Pengganti yang Diputus Berdasarkan Undang-Undang Nomor 3 Tahun 1971 Tentang Pemberantasan Tindak Pidana Korupsi, (Jakarta: Pusat Penelitian dan Pengembangan Kejaksaan Agung, 2016)

Articles:

1) “E-piutang Kejaksaan RI”. Retrieved from http://www.epiutang.kejaksaan.go.id on Juli, 5th 2021 